\title{
Post-Translational Modifications in the Context of Therapeutic Proteins: An Introductory Overview
}

Gary Walsh

\section{1 \\ Introduction}

Many proteins, particularly those derived from eukaryotic sources, undergo covalent modification either during their ribosomal synthesis or (more usually) after synthesis is complete, giving rise to the concept of co-translational and post-translational modification. While the stage during protein synthesis/maturation at which the coor post-translational modification occurs obviously differs, both are often referred to in the literature simply as post-translational modifications (PTMs), a convention also followed in this chapter. These modifications invariably influence some structural aspect or functional role of the affected protein. The main aims of this first chapter is to provide an introductory overview of such modifications, particularly in the context of therapeutic proteins. As such it serves to contextualize the remaining chapters, each of which focuses in detail upon some specific aspect or type of post-translational modification. The initial portion of this chapter serves to introduce biopharmaceuticals and the biopharmaceutical sector. A brief overview of the more common protein PTMs is next provided. The final section then builds upon these two initial sections and overviews issues concerning the PTM complement of therapeutic proteins.

\section{2}

Biopharmaceuticals and the Biopharmaceutical Sector

It is estimated that there are in excess of 4000 biotech companies currently in existence. These are based mainly within the United States and Europe, while the Asia pacific area represents the third largest region [1]. A significant majority of these companies focus upon healthcare biotechnology and the vast majority are research intensive, spending an average of $28 \%$ of revenues on research and development [1].

The biopharmaceutical sector represents the backbone of the global biotech industry. 
This sector can trace its roots back to the late 1970s when the advent of genetic engineering and monoclonal antibody technology underpinned the establishment of hundreds of start-up biopharmaceutical companies. The term "biopharmaceutical" was coined at that time and described therapeutic products produced by modern biotechnological techniques. During the 1980 s this equated exclusively with recombinant proteins and monoclonal antibody-based products. During the1990s the concept of nucleic acid-based drugs for use in gene therapy and antisense technology, as well as the concept of engineered stem and other therapeutic cell lines came to the fore. Such products are also considered biopharmaceuticals but, as outlined below, the vast majority of biopharmaceuticals approved and in clinical trials remain protein-based.

Currently almost 200 biopharmaceutical products have gained approval for general medical use within the EU and/or USA and likely in the region of 350 million people worldwide have been treated with these drugs to date. By the mid-2000s the sector was generating revenues in excess of $\$ 30$ billion, approximately double its global value at the end of the 1990s [2]. Continued strong growth is expected, with the industry projected to reach $\$ 70$ billion by the end of the decade [3, 4]. Typically 8-10 new biopharmaceuticals are approved by global regulatory authorities each year, representing approximately 1 in 4 of all genuinely new drugs coming onto the market.

Profiles of biopharmaceutical products approved thus far are available in various publications (e.g., References [5, 6]) and the major sub-categories of biopharmaceuticals include:

- Antibody-based products (used for in vivo diagnostic and therapeutic purposes).

- Hormone-based products (e.g., recombinant insulins, glucagon, gonadotropins and human growth hormone).

- Subunit vaccines (containing a recombinant antigenic component, e.g., recombinant hepatitis B subunit vaccines).

- Recombinant interferons, interleukins and other cytokines.

- Haematopoietic growth factors (e.g., erythropoietins and colony stimulating factors).

- Recombinant blood factors (factors VIIa, VIII and IX).

- Recombinant thrombolytics (mainly tissue plasminogen activator based products).

- Enzyme-based products (e.g., recombinant DNase and glucocerebrosidase).

Table 1.1 provides a summary of individual products approved within the last 3 years.

\section{3}

\section{Protein Post-Translational Modification}

Proteins can potentially undergo well in excess of 100 different PTMs. Some such modifications (e.g., glycosylation) are common in their occurrence, while others 
1.3 Protein Post-Translational Modification $\mid \mathbf{3}$

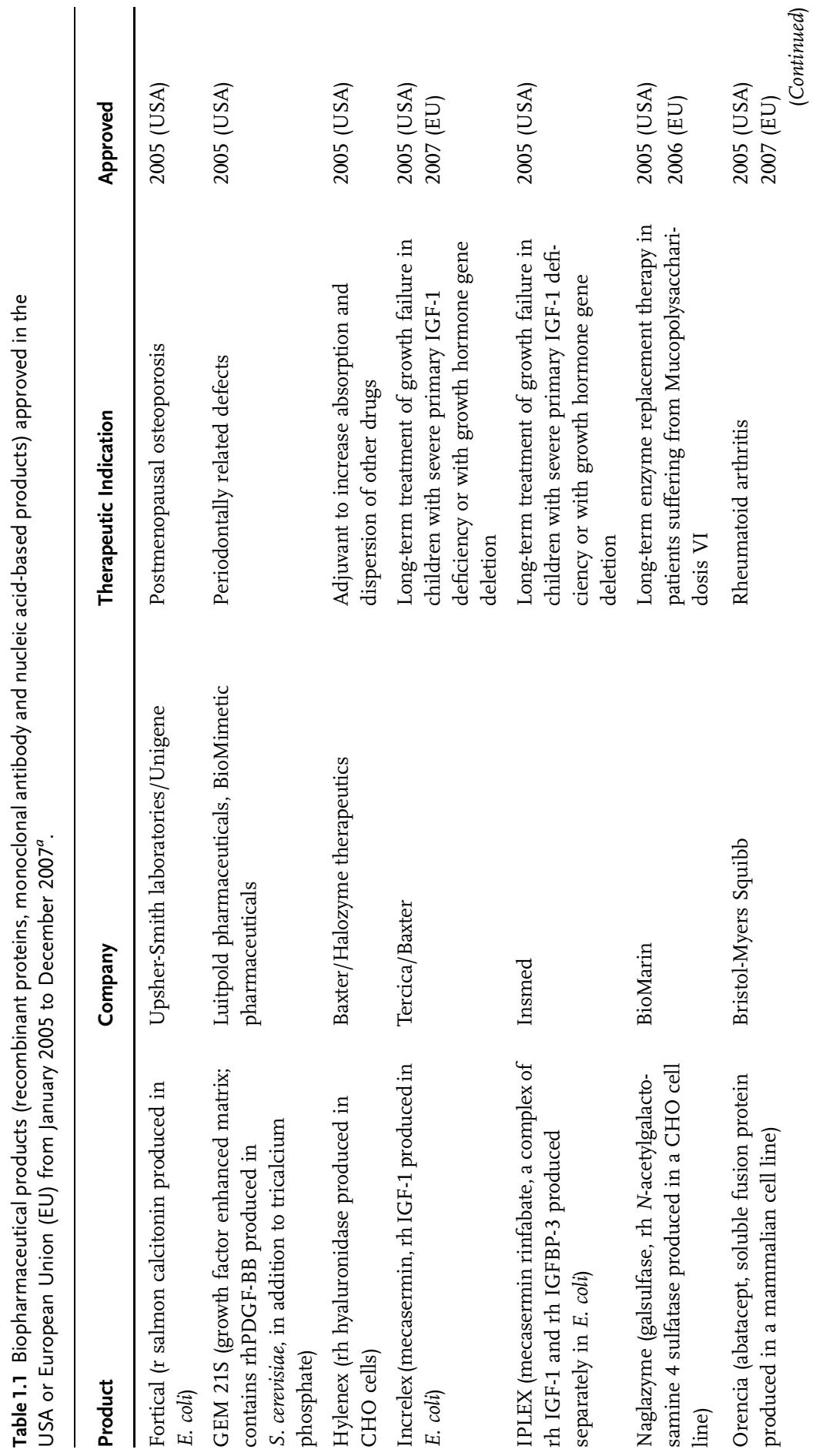




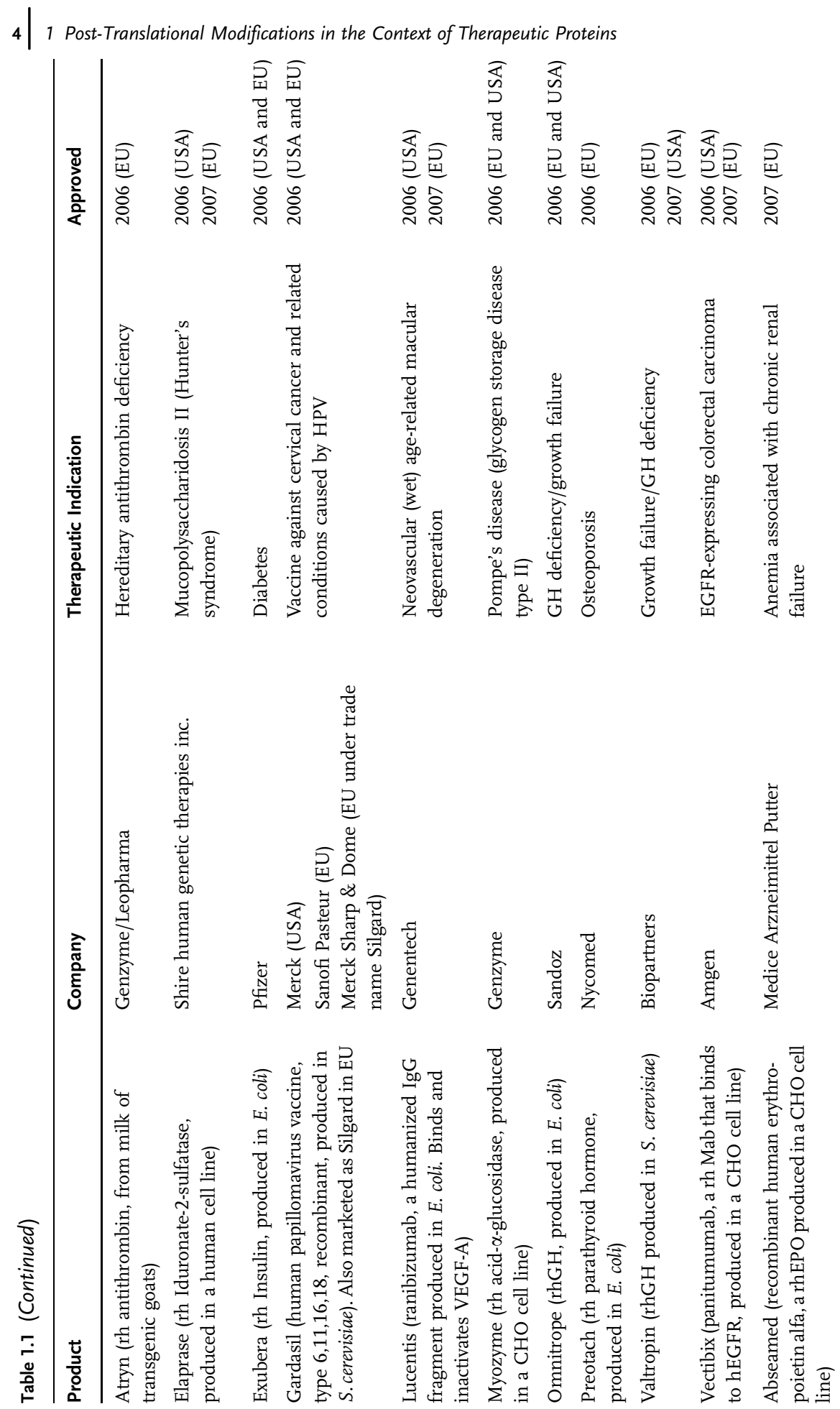




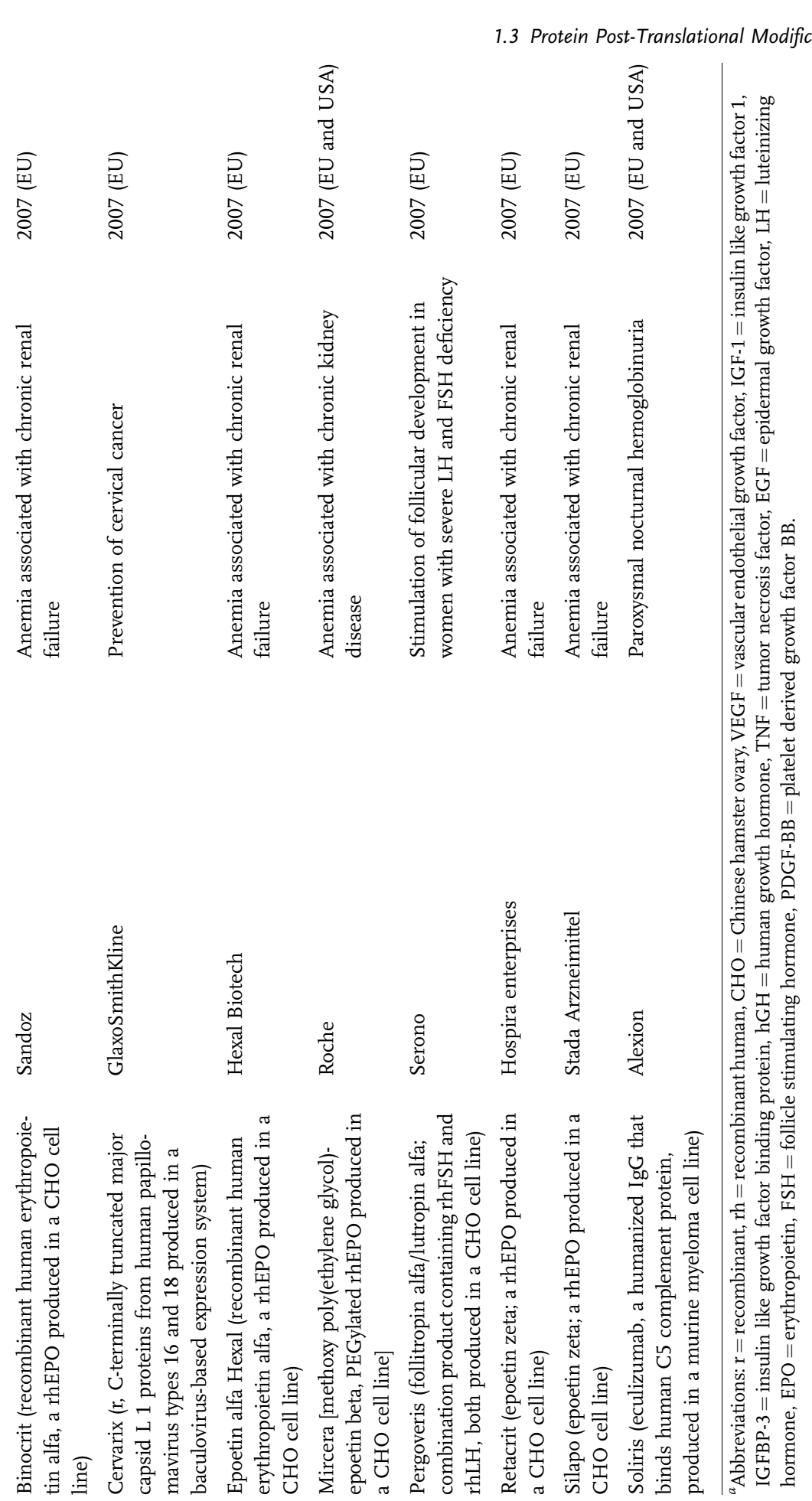


occur only rarely (e.g., selenoylation, the co-translational incorporation of selenium into some proteins). Some PTMs are reversible (e.g., phosphorylation in many cases), while others are irreversible (e.g., proteolysis). Most but not all have an obvious function. Most are introduced into target proteins via specific enzymatic steps/ pathways, while some (e.g., the oxidation of cysteine and methionine residues or the deamidation of asparagine or glutamine residues) arise non-enzymatically. Table 1.2

Table 1.2 Some of the more common post-translational modifications characteristic of proteins.

\begin{tabular}{|c|c|}
\hline Modification & Description/comment \\
\hline Acetylation & $\begin{array}{l}\text { Acetylation (i.e., the incorporation of a } \mathrm{COCH}_{3} \text { group) of the } \\
\mathrm{N} \text {-terminal alpha-amine of polypeptides is a widespread } \\
\text { modification in eukaryotes. It is enzymatically introduced } \\
\text { by } \mathrm{N} \text {-alpha-acetyltransferases. Little is actually known about } \\
\text { the biological role of N-terminal acetylation, although acetylation } \\
\text { of actin is important in the formation of actin filaments }\end{array}$ \\
\hline Acylation & $\begin{array}{l}\text { Acylation [attachment of a (RCO-) group] may help } \\
\text { some polypeptides interact with/anchor in biological } \\
\text { membranes }\end{array}$ \\
\hline ADP-ribosylation & $\begin{array}{l}\text { ADP-ribosylation describes the attachment of one or more ADP } \\
\text { and ribose moieties to a polypeptide's backbone. This modification } \\
\text { is achieved enzymatically by ADP-ribosyltransferase enzymes and } \\
\text { can play various roles in cell signaling and control }\end{array}$ \\
\hline Amidation & $\begin{array}{l}\text { The enzymatic replacement of a polypeptide's C-terminal carboxyl } \\
\text { group with an amide functional group is characteristic of many } \\
\text { bioactive peptides/short polypeptides where it may influence their } \\
\text { biological activity/stability }\end{array}$ \\
\hline $\begin{array}{l}\gamma \text {-Carboxyglutamate } \\
\text { formation }\end{array}$ & $\begin{array}{l}\text { The enzymatic conversion of target glutamate residues into } \\
\gamma \text {-carboxyglutamate. Important in allowing some blood proteins } \\
\text { bind calcium }\end{array}$ \\
\hline Disulfide bond formation & $\begin{array}{l}\text { Disulfide bonds are formed between the thiol }(-\mathrm{SH}) \text { groups } \\
\text { of cysteine residues and generally assist in the folding and } \\
\text { conformational stabilization of some proteins }\end{array}$ \\
\hline Glycosylation & $\begin{array}{l}\text { The covalent attachment of a carbohydrate component to the } \\
\text { polypeptide backbone. For some proteins glycosylation can } \\
\text { increase solubility, influence biological half-life and/or } \\
\text { biological activity }\end{array}$ \\
\hline Hydroxylation & $\begin{array}{l}\text { The enzymatic conversion of target aspartate residues into } \\
\beta \text {-hydroxyaspartate or target asparagine residues into } \beta \text {-hydro- } \\
\text { xyasparagine. Important to the structural assembly of certain } \\
\text { proteins }\end{array}$ \\
\hline Phosphorylation & $\begin{array}{l}\text { The covalent attachment of one or more phosphate groups to the } \\
\text { polypeptide backbone. Often influences/regulates biological } \\
\text { activity of various polypeptide hormones }\end{array}$ \\
\hline Sulfation & $\begin{array}{l}\text { The transfer of } \mathrm{SO}_{3}{ }^{-} \text {group to target tyrosine residues. Influences } \\
\text { biological activity of some neuropeptides and the proteolytic } \\
\text { processing of some polypeptides }\end{array}$ \\
\hline
\end{tabular}


presents a selection of the more common protein PTMs, and further information may be obtained from the references $[7,8]$.

\section{4}

\section{PTMs in the Context of Biopharmaceuticals}

Only a subset of PTMs are generally associated with therapeutic proteins. Protein biopharmaceuticals, with very few exceptions, are recombinant/modified forms of native extracellular proteins. Some PTMs, such as acetylation, ADP ribosylation and phosphorylation, tend to regulate various intracellular processes, including gene expression, endosomal vesicle trafficking and signal transduction, and hence are rarely associated with biopharmaceuticals. PTMs most characteristic of biopharmaceuticals include glycosylation, proteolytic processing and disulfide bond formation, as well as (to a more limited extent) carboxylation, hydroxylation, sulfation and amidation.

Moreover, many biopharmaceuticals bear a combination of two or more PTMs. For example, activated protein C (trade name Xigiris) is carboxylated, hydroxylated, glycosylated, proteolytically processed and houses a disulfide linkage (Figure 1.1).

PTMs can be important, sometimes essential, to the biological activity of many biopharmaceuticals. The exact PTM detail of many recombinant biopharmaceuticals will differ from the PTM profile of the native or "natural" endogenous molecule. Indeed, even when we look at that native product, it is important to remember that its "natural" PTM detailslikely harbors modifications that occurred during its residencetimein blood prior to purification, or which may have occurred during its purification. As such it is not necessary that a specific biopharmaceutical product harbor an exact replica of the PTM complement/detail of its endogenous human counterpart. What is necessary is that clinical trials prove the product (and hence its PTM complement) displays acceptable safety and efficacy, and that quality data prove that the manufacturing process results in the generation of product with consistent structural features, including its PTM profile.

The single largest influence upon PTM detail achieved during production of any recombinant protein is that of the producer cell line chosen in its manufacture. For example, the production of a normally glycosylated protein in Escherichia coli will result in an aglycosylated moiety, while expression in a yeast-based system can result

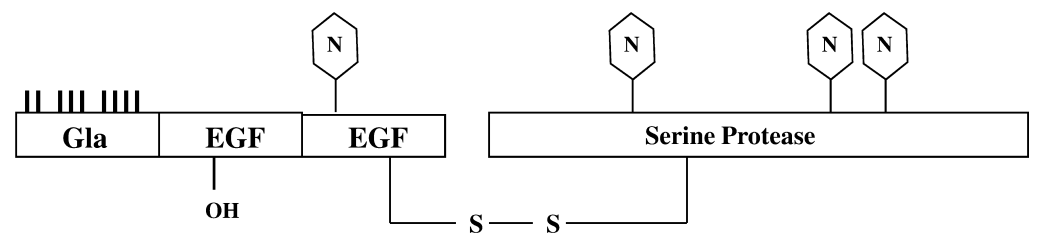

Figure 1.1 Schematic diagram of activated protein $\mathrm{C}$. The protein consists of four domains as shown. The Gla domain houses nine $\gamma$-carboxylation sites. The first EGF domain houses a single $\beta$-hydroxylation site $\left(\mathrm{Asp}^{71}\right)$. Additional PTMs present include proteolytic processing, disulfide bond formation and the attachment of four $\mathrm{N}$-linked carbohydrate side chains. 
in the attachment of sugar side chains high in mannose content, which will negatively influence product serum half-life (Chapter 6). In contrast, production in plant-based systems can result in hyperglycosylated product containing xylose and fucose moieties that are immunogenic in man [9]. Consequently, the use of $\mathrm{CHO}$ or other mammalian cell lines is largely dictated by the latter's ability to undertake appropriate PTMs, generating product with acceptable therapeutic properties (Chapter 3). High expression levels may also overwhelm the PTM machinery, resulting in poor product quality, as shown in the case of some antibodies.

In addition to the production cell line chosen, exact upstream processing conditions employed during manufacture can also influence PTM characteristics. Temperature, growth rate and media composition have, for example, been shown to influence the glycoform profile of several biopharmaceuticals, including tPA and $\gamma$-interferon [10]. Downstream processing can also potentially compromise product integrity by, for example, selectively purifying or enriching a particular PTM product variant. Final product formulation can also have a potential effect by minimizing or preventing chemical-based modification of a PTM.

\section{5}

\section{Some Specific PTMs}

\subsection{1}

\section{Glycosylation}

Glycosylation represents the most complex of all PTMs in the context of therapeutic proteins. As such, the seven chapters in Part 1 of this book are devoted to this topic. Chapter 2 provides a comprehensive overview of the basic science of glycosylation, with subsequent chapters focusing upon the glycosylation characteristics of mammalian, yeast/fungal and insect cell lines and various case studies in the context of specific biopharmaceuticals.

It is estimated that up to $50 \%$ of all native human proteins are glycosylated and that somewhere between 1 and $2 \%$ of the human genome encodes proteins that contribute to glycosylation [11]. The exact glycosylation detail of a therapeutic protein can potentially effect a broad range of functionally significant characteristics:

- Glycosylation can aid in correct protein folding and assembly - for example the glycocomponent of gonadotrophic hormones such as FSH and LH has been implicated in proper protein folding, assembly and secretion).

- It can aid in the targeting and trafficking of a newly synthesized protein to its final destination, be it destined for extracellular secretion or destined for an intracellular organelle. For example, the removal of two or more of EPOs three N-linked glycosylation sites results in a product that is very poorly secreted from a producer cell.

- The glycocomponent can play a direct role in ligand binding, as for example in the case of some gonadotropins. 
- The glycocomponent can play a direct role in triggering a biological activity upon ligand binding - for example removal of the N-52 glycocomponent of gonadotropins actually increases their receptor binding affinity but abolishes their ability to trigger signal transduction upon binding. In other instances it can more indirectly influence biological responses subsequent to ligand binding, as, for example, in the case of antibody triggered ADCC (Chapter 4).

- The glycocomponent may play a direct role in stabilizing the protein - for example $\alpha$-galactosidase (trade name Fabrazyme), an enzyme used to treat Fabry's disease, is glycosylated at asparagine residue184. Removal of the sugar results in protein aggregation and precipitation.

- The glycocomponent often plays a role in regulating a protein's serum half-life. For example, the sialic acid content of EPO has a significant effect on its half-life. Highly branched, highly sialated glycoforms have the longest half-life, while de-sialation results in speedy product removal from the blood (removal of the sialic acid caps exposes terminal galactose residues, thus prompting rapid product removal from the blood via binding to galactose-specific receptors on liver cells).

Table 1.3 lists the therapeutic proteins approved (by the end of 2007) that are glycosylated.

In summary, there were 67 glycosylated products in total, representing one-third of all approved products. The single most significant category of glycosylated product are antibodies, of which there are 23 products listed - the only non-glycosylated antibody-based products are a few antigen-binding fragments approved for in vivo diagnostic purposes.

Table 1.3 Glycosylated biopharmaceuticals that had gained regulatory approval in the EU and/or USA by December 2007.

\begin{tabular}{|c|c|}
\hline Product category & Products (by trade name) \\
\hline Antibodies & $\begin{array}{l}\text { Avastin, Bexxar, Erbitux, Herceptin, Humaspect, Humira, Mabcampath/ } \\
\text { Campath-H1, Mabthera/Rituxan, Mylotarg, Neutrospec, Oncoscint, } \\
\text { Orthoclone OKT-3, Prostascint, Raptiva, Remicade, Simulect, Soliris, } \\
\text { Synagis, Tysabri, Vectibix, Xolair, Zenapax, Zevalin }\end{array}$ \\
\hline $\begin{array}{l}\text { Blood factors, } \\
\text { anticoagulants } \\
\text { and thrombolytics }\end{array}$ & $\begin{array}{l}\text { Activase, Advate, Atryn, Benefix, Bioclate, Helixate/Kogenate, Metalyse/ } \\
\text { TNKase, Novoseven, Recombinate, Refacto, Xigiris }\end{array}$ \\
\hline Hormones & $\begin{array}{l}\text { Gonal F, Luveris, Ovitrelle/Ovidrel, Pergoveris, Puregon/Follistim, } \\
\text { Thyrogen }\end{array}$ \\
\hline EPO and CSFs & $\begin{array}{l}\text { Abseamed, Binocrit, Epoetin alfa hexal, Epogen/Procrit, Leukine, } \\
\text { Mircera, Neorecormon, Nespo/Aranesp, Retacrit, Silapo }\end{array}$ \\
\hline Interferons & Avonex, Rebif \\
\hline Additional & $\begin{array}{l}\text { Aldurazyme, Amevive, Cerezyme, Elaprase, Enbrel, Fabrazyme, Inductos, } \\
\text { Infuse, Myozyme, Naglazyme, Orencia, Osigraft/OP-1 implant, } \\
\text { Pulmozyme, Regranex, Replagal }\end{array}$ \\
\hline
\end{tabular}




\subsection{2}

\section{Disulfide Bond Formation and Proteolytic Cleavage}

Disulfide bond formation and proteolytic cleavage represent two prominent examples of PTMs that introduce structural change into proteins, and both are associated with multiple biopharmaceutical products $[12,13]$. Some products such as therapeutic insulins display both modifications (Figure 1.2).

Disulfide bonds play an important role in the folding and stability of some proteins, usually proteins secreted into the extracellular medium. As cellular compartments are generally reducing environments, disulfide bonds are normally unstable in the cytosol. Table 1.4 presents examples of prominent therapeutic proteins displaying one or more disulfide bonds, and this PTM is considered in more detail in Chapter 11.

Proteolytic cleavage events are also a characteristic modification of many therapeutic and other proteins. Many proteins destined for export or for targeting to specific intracellular organelles are synthesized in an elongated "pro" form, with the "leader sequence" playing a critical role in targeting the protein to its destination. Typically specific proteolytic enzymes then cleave off the "pro" peptide, yielding the mature protein. Proteolysis can also serve as a mechanism of releasing biologically active protein from an inactive (or poorly active) precursor form. Prominent examples here would include several proteases functioning in the digestive tract, as well as the proteolytic processing of proinsulin, yielding the mature insulin product.

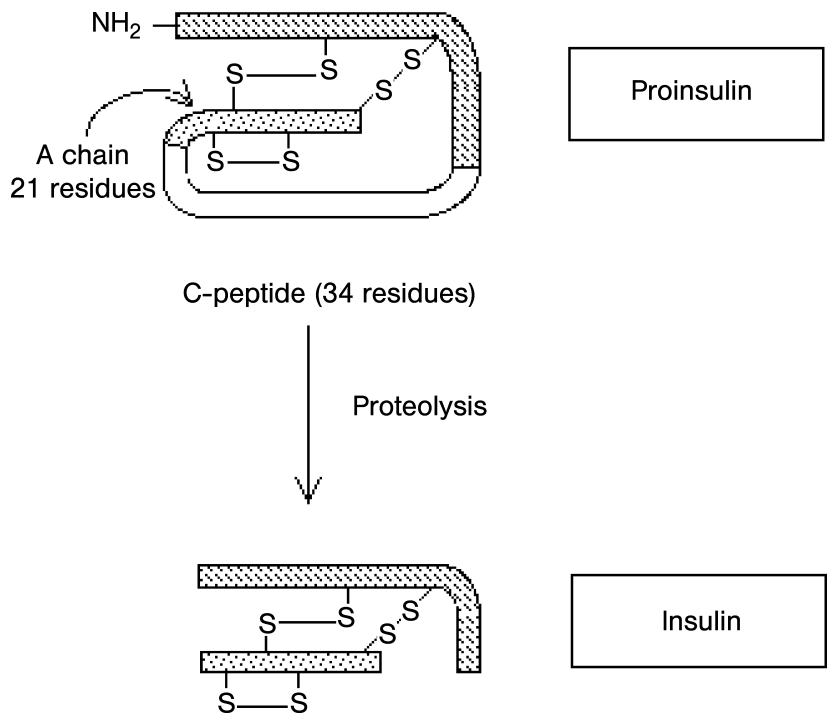

Figure 1.2 Schematic representation of the proteolytic processing of proinsulin, yielding mature insulin, as well as the positions of the disulfide linkages present. (Reproduced with permission from: G. Walsh, (2007) Pharmaceutical Biotechnology, John Wiley \& Sons, Ltd., Chichester, UK.) 
Table 1.4 Examples of some therapeutic proteins that display one or more disulfide linkages ${ }^{a}$.

\begin{tabular}{|c|c|c|}
\hline Protein & Disulfide linkage(s) & Medical application \\
\hline IFN- $\beta$ & $\begin{array}{l}\text { Contains a single intrachain } \\
\text { disulfide linkage }\end{array}$ & Multiple sclerosis \\
\hline IL-2 & $\begin{array}{l}\text { Contains a single intrachain } \\
\text { disulfide linkage }\end{array}$ & Treatment of certain cancers \\
\hline TNF- $\alpha$ & $\begin{array}{l}\text { Contains a single intrachain } \\
\text { disulfide linkage }\end{array}$ & Treatment of soft tissue carcinoma \\
\hline hGH & $\begin{array}{l}\text { Contains two intrachain disulfide } \\
\text { linkages }\end{array}$ & $\begin{array}{l}\text { Treatment of some forms of } \\
\text { dwarfism }\end{array}$ \\
\hline Hirudin & $\begin{array}{l}\text { Contains two intrachain disulfide } \\
\text { linkages }\end{array}$ & Anticoagulant \\
\hline Insulin & $\begin{array}{l}\text { Contains two interchain and one } \\
\text { intrachain disulfide linkages }\end{array}$ & Diabetes \\
\hline Antibodies (IgG) & $\begin{array}{l}\text { Contains two interchain and two } \\
\text { intrachain disulfide linkages }\end{array}$ & Various \\
\hline $\mathrm{tPA}$ & $\begin{array}{l}\text { Contains } 17 \text { intrachain disulfide } \\
\text { linkages }\end{array}$ & Thrombolytic agent \\
\hline
\end{tabular}

${ }^{a}$ Abbreviations: IFN $=$ interferon, $\mathrm{IL}=$ interleukin, $\mathrm{hGH}=$ human growth hormone, $\mathrm{tPA}=$ tissue plasminogen activator.

Proteolytic processing tends not to be problematic during biopharmaceutical manufacture once an appropriate producer cell line has been chosen.

\section{5 .3}

\section{$\gamma$-Carboxylation and $\beta$-Hydroxylation}

$\gamma$-Carboxylation and $\beta$-hydroxylation are PTMs characteristic of a small number of proteins, mainly a subset of proteins involved in blood coagulation [14, 15]. These modifications are undertaken by specific carboxylase and hydroxylase enzymes, with conversion of target glutamate residues in the protein backbone into $\gamma$-carboxyglutamate ( $\mathrm{Glu} \rightarrow \mathrm{Gla}$ ) and target aspartate residues into $\beta$-hydroxyaspartate (Asp $\rightarrow$ Hya). Asparagine residues can also rarely be hydroxylated, forming $\beta$-hydroxyasparagine (Asn $\rightarrow$ Hyn).

Both carboxylation and hydroxylation help mediate the binding of calcium ions, and these PTMs are important, in some cases essential, to the functioning of blood factors VII, IX and X, as well as activated protein $\mathrm{C}$ of the anticoagulant system.

In the context of approved biopharmaceuticals, therefore, carboxylation and/or hydroxylation is significant in the cases Novoseven (Novo's recombinant form of activated blood factor VIIa, indicated for the treatment of both hemophilia A and B), Wyeth's Benefix, (a recombinant version of blood factor IX, used to treat hemophilia B) and Xigiris (recombinant activated protein $\mathrm{C}$, indicated for the treatment of severe sepsis). These PTM are considered in detail in Part 2 (Chapter 9). 
1.5.4

\section{Amidation and Sulfation}

Amidation refers to the replacement of a protein's C-terminal carboxyl group with an amide group. This PTM is characteristic of some bioactive peptides/short polypeptides, including vasopressin, oxytocin, gastrin and calcitonin [16]. While widely associated with higher eukaryotes, amidation is not characteristic of yeast or prokaryotes. The exact biological role(s) of amidation remain to be fully elucidated. It may contribute to peptide stability and/or activity.

Most peptides used in the clinic are manufactured by direct chemical synthesis, including earlier preparations of salmon calcitonin. A recombinant version of this amidated 32 amino acid peptide hormone, however, is now approved for the treatment of Paget's disease and hypercalcemia of malignancy (Forcaltonin, Unigene, UK). Produced in E. coli, forcaltonin initially lacks this PTM and therefore must be subsequently amidated as part of downstream processing. This is achieved enzymatically, using an $\alpha$-amidating enzyme ( $\alpha-\mathrm{AE})$, which is itself produced by recombinant DNA technology using a CHO cell line. Amidation forms the subject matter of Chapter 10.

Sulfation is a PTM that entails the covalent attachment of a sulfate $\left(\mathrm{SO}_{3}{ }^{-}\right)$group, usually via selected tyrosine residues within the protein backbone [17]. Sulfation is performed by a sulfotransferase mediated co/post-translational process, occurring in the trans Golgi network, and is predominantly associated with secretory and membrane proteins. Tyrosine sulfated proteins/sulfotransferases are found in higher eukaryotic species but have not been reported in prokaryotes or in yeast.

Sulfation is apparently not dependant upon the occurrence of a target tyrosine within a strictly defined consensus sequence. However, 3-4 acidic amino acid residues are normally found within five residues of sulfated tyrosines and elements of local secondary structure also likely play a determinant role.

In many instances the function of sulfation remains unknown, although it often plays a role in protein-protein interactions. Generally, the absence of this PTM reduces rather than abolishes activity. In the context of biopharmaceuticals native hirudin and also blood factors VIII and IX are usually sulfated. Neither of the approved recombinant forms of hirudin (Revasc and Refludan, both produced in Saccharomyces cerevisiae) are sulfated and yet are therapeutically effective. Studies, however, have demonstrated that sulfated hirudin displays significantly tighter affinity for thrombin than do unsulfated forms.

While over $90 \%$ of native factor IX molecules are sulfated (at $\operatorname{Tyr}^{155}$ ), less than $15 \%$ of the recombinant form approved (Benefix, produced in a CHO cell line) are, again with apparently little if any difference in therapeutic function.

\section{6}

\section{Extending and Engineering PTM Profiles}

Several approved therapeutic proteins are engineered post-synthesis. This approach normally entails the covalent attachment of a chemical group to the polypeptide's 
backbone, or the alteration of a pre-existing post-translational modification, such as a glycosylation pattern.

The covalent attachment of one or more molecules of poly(ethylene glycol) (PEG) to the polypeptide backbone represents a common form of such engineering [18]. PEGylation generally increases the plasma half-life of the protein drug by reducing the rate of systemic clearance. As a result less frequent dosage regimes are necessitated, with consequent economic savings and (usually) improved patient compliance and convenience. Several PEGylated biopharmaceuticals have gained regulatory approval over the last few years, most notably several interferon-based products. PEGylation is reviewed Part 3 (Chapter 14).

Levemir (trade name) is another therapeutic protein in which a "synthetic" PTM is introduced post-biological synthesis. This long-acting insulin analogue was developed for the treatment of diabetes by Novo. It differs from the native human molecule in that a 14-carbon fatty acid group is covalently attached via the lysine B29 side chain during downstream processing. The fatty acid promotes the binding of insulin to human serum albumin (which has three high-affinity fatty acid binding sites), both at the injection site and in plasma. This in turn ensures constant release of product, giving it duration of action of up to 24 hours [19].

Two approved biopharmaceuticals have been engineered by modification of their carbohydrate component. Cerezyme (trade name) is a carbohydrate-modified form of glucocerebrosidase, a lysosomal enzyme involved in the catalytic degradation of glycolipids. Gaucher's disease is a genetic condition caused by lack of lysosomal glucocerebrosidase activity, with tissue-based macrophages being amongst the most severely effected cell type. The product, which is naturally glycosylated, is produced by recombinant means in a $\mathrm{CHO}$ cell line and downstream processing includes an enzyme-based processing step using an exoglycosidase. The exoglycosidase removes sialic acid sugar residues that cap the oligosaccharide side chains. This exposes mannose residues underneath, facilitating specific uptake by macrophages via macrophage cell surface mannose receptors. In this way the product is specifically targeted to the cell type most affected by the disease. Unmodified glucocerebrosidase, if administered, is quickly removed from the bloodstream by the liver. Cerezyme is reviewed in Chapter 13.

Aranesp (Nespo) is a recombinant form of human erythropoietin (EPO) used to treat anemia associated with chronic renal failure. Produced in a recombinant CHO cell line, it displays an increased overall carbohydrate content when compared to native EPO. The natural molecule harbors three N-linked carbohydrate side chains whereas the recombinant product displays five such side chains. The increased carbohydrate content extends the product's half-life, facilitating once weekly (and in some circumstances once every second week) administration. Aranesp is discussed in detail in Chapter 12.

\section{7}

\section{Conclusion}

PTMs can have a potentially profound influence upon the stability, activity or pharmacokinetics of therapeutic proteins. Characterization of any PTM present, 
along with the establishment of its biological influence(s), represents a critical element of early stage biopharmaceutical drug development. The requirement to routinely manufacture product with an appropriate and reproducible PTM profile is a fundamental concern when developing manufacturing procedures. An increasing understanding of the link between PTM structure and function, particularly in the case of glycosylation, is now facilitating the development of second-generation products displaying PTMs engineered in order to tailor or optimize selected product functional attributes. The issue of post-translational modifications is clearly one of fundamental importance within the biopharmaceutical sector.

\section{References}

1 Lawrence, S. (2007) State of the biotech sector-2006. Nature Biotechnology, 25, 706.

2 Lawrence, S. (2005) Biotech drug market steadily expands. Nature Biotechnology, 23, 1466.

3 Pavlou, A. and Belsey, M. (2005) The therapeutic antibody market to 2008 . European Journal of Pharmaceutics and Biopharmaceutics, 59, 389-396.

4 Pavlou, A. and Reichert, J. (2004) Recombinant protein therapeutics success rates, market trends and values to 2010. Nature Biotechnology, 22, 1513-1519.

5 Walsh, G. (2006) Biopharmaceutical benchmarks 2006. Nature Biotechnology, 24, 769-776.

6 Rader, R. (2007) Biopharmaceutical Products in the US and the European Markets, 6thedn, Bioplan Associates, Rockville, MD.

7 Higgins, S. and Hames, B. (1999) Post Translational Processing, a Practical Approach, Oxford University Press.

8 Kannicht, C. (2002) Post Translational Modification of Proteins, Humana Press, USA.

9 Gomord, V. et al. (2004) Production and glycosylation of plant made pharmaceuticals: the antibodies as a challenge. Plant Biotechnology Journal, 2, 83-100.

10 Butler, M. (2005) Animal cell culture: recent achievements and perspectives in the production of biopharmaceuticals. Applied Microbiology and Biotechnology, 68, 283-291.
11 Walsh, G. and Jefferis, R. (2006) Post translational modifications in the context of therapeutic proteins. Nature Biotechnology, 24, 1241-1252.

12 Steiner, D. et al. (1974) Proteolytic processing in the biosynthesis of insulin and other proteins. Federation Proceedings, 33, 2105-2115.

13 Sevier, C.S. and Kaiser, C.A. (2002) Formation and transfer of disulphide bonds in living cells. Nature Reviews Mollecular and Cellular Biology, 3, 836-847.

14 Hansson, K. and Stenflo, J. (2005) Post translational modifications in proteins involved in blood coagulation. Journal of Thrombosis and Haemostasis, 3, 2633-2648.

15 Kaufman, R. (1998) Post translational modifications required for coagulation factor secretion and function. Thrombosis and Haemostasis, 79, 1068-1079.

16 Bradbury, A. and Smyth, D. (1991) Peptide amidation. Trends in Biochemical Science, 16, 112-115.

17 Moore, K. (2003) The biology and enzymology of protein tyrosine-Osulfation. Journal of Biological Chemistry, 278, 24243-24246.

18 Veronese, F. and Pasut, G. (2005) PEGylation, successful approaches to drug delivery. Drug Discovery Today, 10, 1451-1458.

19 Goldman-Levine, J. and Lee, K. (2005) Insulin detemir - a new basal insulin analogue. Annals of Pharmacotheraphy, 39, 502-507. 